\title{
THE ROLE OF INDIAN COSTUS AGAINST TOXICITY OF THERMALLY OXIDIZED PALM OIL IN ALBINO RATS
}

\author{
Mofrih M Hegazy', Osama M Abonama², Asmaa S Mohammad ${ }^{3}$, Elsayed S \\ Abouelnour ${ }^{4}$, Mohammad M Badr ${ }^{5}$, Ibrahim A Elhalfawy ${ }^{6}$ \\ ${ }^{1}$ Forensic Medicine and Clinical Toxicology Department, Faculty of Medicine, Menoufia \\ University. \\ ${ }^{2}$ Industrial Biotechnology Department, Genetic Engineering and Biotechnology Research \\ Institute, Sadat City University, \\ ${ }^{3}$ Pathology Department, Faculty of Medicine, Menoufia University, Egypt. \\ ${ }^{4}$ Medical Biochemistry and Molecular Biology Department, Faculty of Medicine, Menoufia \\ University. \\ ${ }^{5}$ Biochemistry Department, Faculty of Pharmacy, Menoufia. \\ ${ }^{6}$ Molecular Diagnostics and Therapeutics Department, Genetic Engineering and \\ Biotechnology Research Institute, Sadat City University. \\ Corresponding author: \\ Mofrih M. Hegazy \\ Assistant professor in Forensic Medicine and Clinical Toxicology Department, Faculty of \\ Medicine, Menoufia University, Egypt. \\ E. mail: mofrihhegazy@yahoo.com \\ Mobile phone: 01012897290
}

\begin{abstract}
Background: Indian Costus extract used as traditional herbal therapy for various diseases. Ingestion of thermally oxidized palm oil causes oxidative stress leading to multiple health problems such as hypertension, dyslipidemia, atherosclerosis, as well as kidneys and liver abnormality. Aim: To investigate the toxic effects of thermally oxidized palm oil on the liver, kidneys, heart and lung of Albino rats and to evaluate the role of Indian costus in improving these effects. Methods: Forty adult healthy male albino rats equally assigned into four groups and gavaged by a single daily dose for 45 days as follows group I (control group) gavaged by distilled water, group II gavaged by $80 \mathrm{mg} / \mathrm{kg}$ of Indian costus extract, group III gavaged by one-tenth LD50 of thermally oxidized palm oil (LD50 equal $18 \mathrm{gm} / \mathrm{kg}$ ) and group IV gavaged as group III in addition to $80 \mathrm{mg} / \mathrm{kg}$ of Indian costus extract. Serum was collected for biochemical analyses for liver, kidney function tests, lipid profile, malondialdehyde (MDA) and total antioxidant capacity. Also, histological examination for livers, kidneys, heart, and lung from sacrificed rats of all groups were performed. Results: A significant increase in total cholesterol, triacylglycerol, low-density lipoprotein, alanine aminotransferase and aspartate aminotransferase in group III compared to group I but group IV had significantly lower levels of theses parameters than group III. The highest levels of MDA were in group III followed by group IV and the lowest levels were in group II. There was significant lower mean level of MDA in group IV than group III $(7.31 \pm 0.60$ vs $8.25 \pm 1.01$; respectively). There were significant higher prevalence of steatosis, congestion, and hepatitis in the liver of group III than group IV ( $\mathrm{p}=0.004,0.014$ and 0.012 ; respectively). Also, there was a significant higher prevalence of atheroma in the heart, moderate and severe interstitial inflammation, and granuloma around cholesterol crystal in the lung, cloudy swelling, and congestion in the kidneys of group III than group IV.

Conclusion: Thermally oxidized palm oil had a deleterious effect on liver, kidney, lung and heart ultrastructure, induces hyperlipidemia and oxidative stress. The extract of Indian costus had a potential protective effect against these effects.
\end{abstract}

Key words: Thermally oxidized palm oil; Indian costus; Liver; Kidney; Heart; Lung. 


\section{INTRODUCTION}

Palm oil is the most widely produced edible vegetable oil in the world. It is obtained from the reddish pulp of the fruit of the oil palm tree. It is naturally reddish in color due to its high content of betacarotene (Nwalieji and Ojike, 2018). Crude palm oil is the richest source of carotenoids. Also, palm oil is rich with saturated fatty acids as palmitic acid and contains small proportions of unsaturated fatty acids as oleic and linoleic acids (Mukherjee and Mitra, 2009).

In Egypt, palm oil is widely used in food industry as cheese making, bakery products and many industries (Chandrasekharan et al., 2000). Also, the use of thermally oxidized palm oil has been a usual practice in homes due to its economic advantages over other oils/fats and to increase its palatability (Ismail, 2005). Ingestion of thermally oxidized palm oil has been reported to cause various functional and structural alterations (Falade et al., 2015). These potentially toxic effects result from peroxidation of polysaturated fatty acids (Obeten et al., 2014).

Saussurea costus, synonymous as Saussurea lappa Clarke (Parmar et al., 2012) belong to the genus Asteraceae (Singh et al., 2017) and commonly known as Indian costus (Gwari et al., 2013) or Kuth root (Amara et al., 2017). It was used as a medicinal plant for the treatment of various ailments as asthma, inflammatory diseases, ulcer and stomach problems (Pandey et al., 2007). Moreover, costus has been mentioned in Prophet's medicine for treatment of many diseases (AL-Kattan, 2013) and was used in modern medicine (Amara et al., 2017).

The Saussurea (costus) is one of the antioxidant-rich medicinal plants (Saleem et al., 2013). The major components are sesquiterpene lactones such as costunolide and dehydrocostus lactone. It has various biological activities such as, antiinflammatory, immune-modulator, hypoglycemic, anti-hepatotoxic, hypolipidemic, antiparasitic, antiviral and anticancer activities (Zahara et al 2014; Amara et al 2017).

The present study was carried out to investigate the toxic effects of thermally oxidized palm oil on the liver, kidneys, heart and lung of Albino rats and to evaluate the role of Indian costus in improving these effects through biochemical and histological evaluation.

\section{MATERIALS AND METHODS}

\section{I: Materials:}

- Raw Malaysian palm oil (2 L) was purchased from Integrated Suez Company for Oils. One portion was oxidized by subjecting it to heating in a stainless steel frypan for $20 \mathrm{~min}$ at $180{ }^{\circ} \mathrm{C}$. (Falade et al (2015).

- The dry roots of Saussurea costus were purchased from local herbal market in Cairo. It is identified as Saussurea costus in faculty of pharmacy - Menoufia University

- Plant Processing and Extraction: The powder root of Costus afer $(500 \mathrm{~g})$ was soaked in $2500 \mathrm{ml}$ of ethanol $(70 \%)$ for $72 \mathrm{~h}$. The extract was filtered using Watman No. 1 filter paper and subsequently concentrated at $45^{\circ} \mathrm{C}$ using a rotary evaporator and stored at $4^{\circ} \mathrm{C}(\mathrm{R})$ (Tonkiri et al 2015). Ethanolic extract of S. lappa was studied at a dose range of 50$200 \mathrm{mg} / \mathrm{kg}$, for the acute and chronic inflammation induced in rats (Zahara et al 2014). Aqueous extract at a dose $50 \mathrm{mg} / \mathrm{kg}$ body weight was tested in rats (Abd Eldaim et al 2019).

II: Methods: Forty adult healthy male albino rats weighing $125-150$ gm body weight were included in this study from the 5th September to the 20th of October 2018. The rats were acclimatized for one week then they were randomly allocated into 4 groups, 10 animals in each group and was gavaged by; a single daily dose of distilled water in group (control group); Indian costus extract (therapeutic 80 $\mathrm{mg} / \mathrm{kg}$ ) in group II; a single daily dose of one-tenth LD50 (LD50 equal $18 \mathrm{gm} / \mathrm{kg}$ ) 
(Bassan et al 2012) of thermally oxidized palm oil in group III and a single daily dose of $80 \mathrm{mg} / \mathrm{kg}$ Indian costus extract and one-tenth LD50 (LD50 equal 18 $\mathrm{gm} / \mathrm{kg}$ ) of thermally oxidized palm oil in group IV. All animals received the above doses daily for 45 days. The study applied the double-blind technique for both the administrator of animal feed and materials and the investigators of biochemical and histopathological examinations.

\section{Biochemical assessment}

On the forty-six day of the experiment, blood samples were collected from the orbital plexus of veins of all rats of the studied groups. Serum was separated by centrifugation at $3000 \mathrm{rpm}$ for $15 \mathrm{~min}$ and was stored at $-20{ }^{\circ} \mathrm{C}$ till the time of assay.

-Total lipids were measured by spectrophotometry using Reactivos GPL kid from Chemelex, Barcelona, Spain. (Young, 2001).

-Determination of Serum Total Cholesterol, triacylglycerols, high density lipoproteins were determined by enzymatic colorimetric test, using kits supplied by SPINREACT, Spain. LDLc was calculated according to the formula (Rifai et al., 2006).

-Lipid peroxide (Malondialdehyde) and total antioxidant capacity (TAC) were assessed by Colorimetric method (Biodiagnostic, Egypt) (Ohkawa et al., 1979; koracevic et al., 2001).

-Assay of serum alanine aminotransferase (ALT) and serum aspartate aminotransferase (AST) was done using kinetic UV method, the concentration was calculated using $\Delta$ absorbance/minute with factor which was 1746 at $37{ }^{\circ} \mathrm{C}$ (Henderson and Moss, 2001).

- Measurement of serum albumin was done using modified bromocresol green colorimetric method. The concentration was determined by measuring the absorbance at $630 \mathrm{~nm}$ and comparison with the absorbance of the standard solution (Doumas et al., 1971).
- Assay of alkaline phosphatase enynzyme activity was done by spectrophotometry, kinetic assay using a kit from Biomed, Egypt (Scherwin, 2003).

- Urea was determined by Berthelot enzymatic colorimetric method. Using urease to hydrolyse urea into ammonia and carbon dioxid. The concentration was determined by measuring the absorbance at $572 \mathrm{~nm}$ (Kaplan, 1984).

Creatinine was determined spectrophotometrically by the kinetic method (Diamond). The absorbance was read at 30 seconds and 2 minutes later. Creatinine concentration was calculated using standard concentration which is 2 mg/dl (Henry, 1974).

- B2 microglobulin were determinated by competitive chemiluminescence method using a kid provided from Diasorin, Italy using Liaison analyzer Italy (TurbatHerrera, 1994).

- Creatine kinase (CK) was determined spectrophotometrically, kinetic assay, UV method using a kid from Biomed, Egypt (Young, 2001).

Assay of serum lactate dehydrogenase (LDH) was determined spectrophotometrically, kinetic assay, using a kid from Biomed, Egypt. (Pesce, 1984)

\section{Histopathological evaluation:}

Animal painless procedures were conducted with appropriate sedation to avoid pain and stress under general inhalation of ether anesthesia. Collected livers, kidneys, heart, and lung from sacrificed albino rats of all groups were prepared for histological examination by fixation in $10 \%$ formalin and kept in the fixative overnight. Then, they were dehydrated in an ascending grade of alcohol (70\%, 80\%, 95\% and 100\% ethanol for $1 \mathrm{~h}$ for each concentration), cleared in xylene and embedded in paraffin wax. Serial sections of $5 \mathrm{~mm}$ thickness were obtained using a rotatory microtome. The deparaffinized sections were stained routinely with hematoxylin and eosin 
reagent. Photomicrographs of the specimens were obtained using digital research photographic microscope

(Ramos-Vara et al., 2017).

-Biopsy specimens from the 4 groups were collected then paraffin blocks were prepared and haematoxylin and eosin slides were evaluated by histopatholoical examination as follow:

Liver specimens were evaluated for:

1) Congestion: according to degree of venous and sinusoidal congestion, cases were evaluated into mild, moderate and severely congested.

2) Steatosis: was assessed by NAFLD activity Score (NAS) according to percent of hepatocytes containing fat droplets, cases were evaluated into :

S0: $\rightarrow<5 \%$

3) S1: Mild steatosis-- $\rightarrow 5-33 \%$ of hepatocytes

S2: Moderate steatosis--- $\rightarrow$ 34-66\%

S3: Sever steatosis-- $\rightarrow>66 \%$ (Kleiner et al., 2005).

4) Hepatitis: degree of activity and degree of liver cell injury (grading of hepatitis) were evaluated by using Ishak scoring system and cases were divided into mild, moderate and sever hepatitis (Brunt, 2000).

Kidney specimens were evaluated for: Presence or absence of any pathologic abnormalities including cloudy swelling of tubules, congestion of renal vessels and thickening of renal vessels (close and phrase).

Heart specimens were evaluated for:

1-Degree of congestion of cardiac blood vessels
2- Presence or absence of atheroma changes in the wall of cardiac vasculature.

Lung specimens were evaluated for:

Presence or absence of

1-Chronic interstitial inflammation: graded according to its severity into mild, moderate and sever.

2-Granuloma around cholesterol crystals

The use of experimental animals was prospectively approved by the Ethical Committee, Faculty of Medicine, Menoufia University.

\section{Statistical analysis:}

Data was statistically analyzed by SPSS Version 20 software (SPSS, Chicago, IL, USA) on an IBM compatible computer. Mean, standard deviation (SD), number and percent were described. One way analysis of variance (ANOVA) test was applied for comparison between the studied groups regarding the quantitative variables followed by (LSD) post hoc test. A P-value $\leq 0.05$ was considered statistically significant.

\section{RESULTS}

There were significant differences between the studied groups regarding the mean levels of all lipid profile parameters $(p<0.001)$. The highest levels of lipid profile parameters were in group III followed by group IV and the lowest levels were in group II. Group IV had significant lower mean values of total lipid, cholesterol, TG and LDL than group III $(\mathrm{p}=0.001,0.018,<0.001,<0.001$ and 0.013 ; respectively) while HDL levels were significantly higher in group IV than group III ( $\mathrm{p} 6=0.013)$ as shown in Table 1 
Table (1: Comparison between the studied groups regarding lipid profile.

\begin{tabular}{|c|c|c|c|}
\hline Lipid profile & Groups & Mean \pm SD & p-value \\
\hline \multirow{7}{*}{$\begin{array}{l}\text { Total lipid } \\
(\mathrm{mg} / \mathrm{dl})\end{array}$} & Group I & $633.40 \pm 91.22$ & \multirow{7}{*}{$\begin{array}{c}<0.001 \\
\text { P1:0.023 } \\
\text { P2: }<0.001 \\
\text { P3: }<0.001 \\
\text { P4: }<0.001 \\
\text { P5: }<0.001 \\
\text { P6: } 0.001\end{array}$} \\
\hline & Group II & $559.60 \pm 54.74$ & \\
\hline & Group III & $957.00 \pm 36.06$ & \\
\hline & \multirow[t]{4}{*}{ Group IV } & \multirow[t]{4}{*}{$872.30 \pm 34.57$} & \\
\hline & & & \\
\hline & & & \\
\hline & & & \\
\hline \multirow{7}{*}{$\begin{array}{c}\text { Cholesterol } \\
(\mathrm{mg} / \mathrm{dl})\end{array}$} & Group I & $140.70 \pm 7.72$ & \multirow{7}{*}{$\begin{array}{c}<0.001 \\
\text { P1: } 0.018 \\
\text { P2: }<0.001 \\
\text { P3: }<0.001 \\
\text { P4: }<0.001 \\
\text { P5: }<0.001 \\
\text { P6: }<0.001\end{array}$} \\
\hline & Group II & $117.50 \pm 9.34$ & \\
\hline & Group III & $244.60 \pm 38.85$ & \\
\hline & \multirow[t]{4}{*}{ Group IV } & \multirow[t]{4}{*}{$200.10 \pm 8.12$} & \\
\hline & & & \\
\hline & & & \\
\hline & & & \\
\hline \multirow[t]{7}{*}{ TG (mg/dl) } & Group I & $107.80 \pm 10.76$ & \multirow{7}{*}{$\begin{array}{c}<0.001 \\
\mathrm{P} 1:<0.001 \\
\mathrm{P} 2:<0.001 \\
\mathrm{P} 3:<0.001 \\
\mathrm{P} 4:<0.001 \\
\mathrm{P} 5:<0.001 \\
\mathrm{P} 6:<0.001\end{array}$} \\
\hline & Group II & $87.20 \pm 7.32$ & \\
\hline & Group III & $164.50 \pm 6.47$ & \\
\hline & Group IV & $151.10 \pm 6.74$ & \\
\hline & & & \\
\hline & & & \\
\hline & & & \\
\hline \multirow[t]{7}{*}{ HDL } & Group I & $56.60 \pm 4.40$ & \multirow{7}{*}{$\begin{array}{c}<0.001 \\
\text { P1: } 0.003 \\
\text { P2: }<0.001 \\
\text { P3: }<0.001 \\
\text { P4: }<0.001 \\
\text { P5: }<0.001 \\
\text { P6: } 0.013\end{array}$} \\
\hline & Group II & $63.90 \pm 3.67$ & \\
\hline & Group III & $26.50 \pm 4.97$ & \\
\hline & Group IV & $30.60 \pm 3.60$ & \\
\hline & & & \\
\hline & & & \\
\hline & & & \\
\hline \multirow[t]{7}{*}{ LDL (mg/dl) } & Group I & $105.90 \pm 11.95$ & \multirow{7}{*}{$\begin{array}{c}<0.001 \\
\text { P1:0.003 } \\
\text { P2: }<0.001 \\
\text { P3: }<0.001 \\
\text { P4: }<0.001 \\
\text { P5: }<0.001 \\
\text { P6: } 0.013\end{array}$} \\
\hline & Group II & $87.80 \pm 7.89$ & \\
\hline & Group III & $164.60 \pm 5.93$ & \\
\hline & Group IV & $153.20 \pm 5.22$ & \\
\hline & & & \\
\hline & & & \\
\hline & & & \\
\hline
\end{tabular}

\begin{tabular}{|c|c|c|}
\hline P1: group I vs group II & $\begin{array}{c}\text { P3: group I vs group } \\
\text { IV }\end{array}$ & P5: group II vs group IV \\
\hline P2: group I vs group III & $\begin{array}{c}\text { P4: group II vs group } \\
\text { III }\end{array}$ & P6: group III vs group IV \\
\hline
\end{tabular}


The studied groups had significant differences regarding the mean levels of MDA and TAC $(p<0.001)$. The highest levels of MDA were in group III followed by group IV and the lowest levels were in group II. There was significant lower mean level of MDA in group IV than group III $(7.31 \pm 0.60$ vs $8.25 \pm 1.01$, p6 $=0.008)$ On the other hand, the highest levels of TAC were in group II followed by group I and the lowest levels were in group III. There was a significant higher mean level of TAC in group IV than group III $(0.58 \pm 0.14$ vs $0.42 \pm 0.11, \mathrm{p} 6=0.025)$ as shown in Table 2.

Table (2): Comparison between the studied groups regarding MDA and TAC levels.

\begin{tabular}{|l|l|l|l|}
\hline Variables & Groups & Mean \pm SD & p-value \\
\hline MDA (mmol/L) & Group I & $4.14 \pm 0.98$ & $<0.001$ \\
\cline { 2 - 3 } & Group II & $2.56 \pm 0.89$ & P1:0.001 \\
\cline { 2 - 3 } & Group III & $8.25 \pm 1.01$ & P3: $<0.001$ \\
& Group IV & $7.31 \pm 0.60$ & P4: $<0.001$ \\
& & & P5: $<0.001$ \\
& & & P6:0.008 \\
\hline TAC $(\mathrm{mmol} / \mathrm{L})$ & Group I & $0.93 \pm 0.44$ & $<0.001$ \\
\cline { 2 - 3 } & Group II & $1.81 \pm 0.40$ & $\mathrm{P} 1: 0.001$ \\
\cline { 2 - 3 } & Group III & $0.42 \pm 0.11$ & $\mathrm{P} 2:<0.001$ \\
\cline { 2 - 4 } & Group IV & $0.58 \pm 0.14$ & $\mathrm{P} 3:<0.001$ \\
& & & $\mathrm{P} 4:<0.001$ \\
& & & $\mathrm{P} 5:<0.001$ \\
& & & P6:0.023 \\
\hline
\end{tabular}

\begin{tabular}{|l|l|l|}
\hline P1: group I vs group II & $\begin{array}{l}\text { P3: group I vs group } \\
\text { IV }\end{array}$ & P5: group II vs group IV \\
\hline P2: group I vs group III & $\begin{array}{l}\text { P4: group II vs group } \\
\text { III }\end{array}$ & $\begin{array}{l}\text { P6: group III vs group } \\
\text { IV }\end{array}$ \\
\hline
\end{tabular}

All liver function tests (ALT, AST, albumin, and alkaline phosphatase) showed no significant difference between group I and group II ( $\mathrm{p} 1>0.05)$. There were significant higher mean levels of ALT and AST in group III and in group IV than group I (p2 and p3=<0.001). Also, there were significant lower mean levels of
ALT and AST in group IV than group III (p6=0.002 and <0.001; respectively). There were no significant differences in the mean levels of albumin or alkaline phosphatase between the studied groups ( $\mathrm{p}=0.187$ and 0.942 ; respectively) as shown in Table 3 
Table (3): Comparison between the studied groups regarding liver function tests.

\begin{tabular}{|c|c|c|c|}
\hline Variables & Groups & Mean \pm SD & p-value \\
\hline \multirow[t]{4}{*}{ ALT } & Group I & $29.10 \pm 7.23$ & \multirow{4}{*}{$\begin{array}{l}<0.001 \\
\text { P1:0.330 } \\
\text { P2: }<0.001 \\
\text { P3: }<0.001 \\
\text { P4: }<0.001 \\
\text { P5: }<0.001 \\
\text { P6: } 0.002\end{array}$} \\
\hline & Group II & $25.40 \pm 6.04$ & \\
\hline & Group III & $61.40 \pm 10.01$ & \\
\hline & Group IV & $51.50 \pm 7.01$ & \\
\hline \multirow[t]{4}{*}{ AST } & Group I & $25.30 \pm 4.32$ & \multirow{4}{*}{$\begin{array}{l}<0.001 \\
\text { P1: } 0.102 \\
\text { P2: }<0.001 \\
\text { P3: }<0.001 \\
\text { P4: }<0.001 \\
\text { P5: }<0.001 \\
\text { P6: }<0.001\end{array}$} \\
\hline & Group II & $21.00 \pm 5.50$ & \\
\hline & Group III & $57.30 \pm 5.03$ & \\
\hline & Group IV & $49.20 \pm 4.42$ & \\
\hline \multirow[t]{4}{*}{ Albumin } & Group I & $4.13 \pm 0.53$ & \multirow{4}{*}{$\begin{array}{l}0.187 \\
\text { P1:0.116 } \\
\text { P2:0.734 } \\
\text { P3:0.809 } \\
\text { P4:0.058 } \\
\text { P5:0.066 } \\
\text { P6:0.915 }\end{array}$} \\
\hline & Group II & $8.46 \pm 12.15$ & \\
\hline & Group III & $3.21 \pm 0.53$ & \\
\hline & Group IV & $3.35 \pm 0.42$ & \\
\hline \multirow{4}{*}{$\begin{array}{l}\text { Alkaline } \\
\text { phosphatase }\end{array}$} & Group I & $286.30 \pm 74.12$ & \multirow{4}{*}{$\begin{array}{l}0.942 \\
\text { P1:0.577 } \\
\text { P2:0.612 } \\
\text { P3:0.729 } \\
\text { P4:0.960 } \\
\text { P5:0.821 } \\
\text { P6:0.862 }\end{array}$} \\
\hline & Group II & $307.30 \pm 72.70$ & \\
\hline & Group III & $305.40 \pm 86.83$ & \\
\hline & Group IV & $290.20 \pm 96.52$ & \\
\hline
\end{tabular}

\begin{tabular}{|l|l|l|}
\hline P1: group I vs group II & $\begin{array}{l}\text { P3: group I vs group } \\
\text { IV }\end{array}$ & P5: group II vs group IV \\
\hline P2: group I vs group III & $\begin{array}{l}\text { P4: group II vs group } \\
\text { III }\end{array}$ & $\begin{array}{l}\text { P6: group III vs group } \\
\text { IV }\end{array}$ \\
\hline
\end{tabular}

The studied groups had no significant differences in the mean levels of urea, creatinine or B2 microglobulin ( $\mathrm{p}=0.946$, 0.806 and 0.823 ; respectively) as shown in Table 4. 
Table (4): Comparison between the studied groups regarding kidney function tests.

\begin{tabular}{|l|l|l|l|}
\hline Variables & Groups & Mean \pm SD & p- value \\
\hline Urea & Group I & $26.40 \pm 7.83$ & 0.964 \\
& Group II & $26.20 \pm 7.33$ & P1:0.948 \\
\cline { 2 - 3 } & Group III & $28.90 \pm 6.49$ & P2:0.871 \\
\cline { 2 - 3 } & Group IV & $25.90 \pm 5.93$ & P3:0.971 \\
& & & P4:0.820 \\
& & & P5:0.971 \\
\hline Creatinine & Group I & $0.60 \pm 0.18$ & P6:0.788 \\
\cline { 2 - 3 } & Group II & $0.62 \pm 0.20$ & P1:06.817 \\
\cline { 2 - 3 } & Group III & $0.64 \pm 0.20$ & P2:0.644 \\
\cline { 2 - 3 } & Group IV & $0.62 \pm 0.19$ & P3:0.667 \\
& & & P4:0.817 \\
& & & P5:0.846 \\
& & & P6:0.966 \\
\hline B2 & Group I & $1440.50 \pm 409.99$ & 0.823 \\
\cline { 2 - 3 } & Group II & $1329.20 \pm 364.01$ & P1:0.513 \\
\cline { 2 - 3 } & Group III & $1333.10 \pm 425.88$ & P2:0.528 \\
\cline { 2 - 3 } & Group IV & $1436.60 \pm 316.51$ & P3:0.974 \\
& & & P4:0.982 \\
& & & P5:0.483 \\
& & & P6:0.479 \\
\hline
\end{tabular}

The mean levels of CK-MB or LDH didn't significantly changed between the studied groups ( $\mathrm{p}=0.934$ and 0.708 ; respectively) as shown in Table 5

Table (5): Comparison between the studied groups regarding CKMB and LDH.

\begin{tabular}{|l|l|l|l|}
\hline Variables & Groups & Mean \pm SD & p- value \\
\hline CKMB & Group I & $14.40 \pm 4.22$ & 0.934 \\
\cline { 2 - 3 } & Group II & $15.40 \pm 3.78$ & P1:0.604 \\
\cline { 2 - 3 } & Group III & $14.30 \pm 4.47$ & P2.0.959 \\
\cline { 2 - 3 } & Group IV & $14.60 \pm 4.67$ & P3:0.787 \\
& & P4:0.568 \\
& & & P5:0.794 \\
\hline \multirow{4}{*}{ LDH } & Group I & $241.30 \pm 54.28$ & 0.708 \\
\cline { 2 - 3 } & Group II & $215.10 \pm 47.40$ & P1:0.533 \\
\cline { 2 - 3 } & Group III & $235.40 \pm 125.50$ & P2:0.888 \\
\cline { 2 - 3 } & Group IV & $202.10 \pm 120.35$ & P3:0.299 \\
& & & P4:0.629 \\
& & & P5:0.685 \\
& & & P6:0.369 \\
\hline
\end{tabular}

Table 6 showed a significant higher prevalence of steatosis, congestion, and hepatitis in the liver of group III than group IV ( $\mathrm{p}=0.004,0.014$ and 0.012 ; respectively) photomicrograph (1a), (1b) and (1c). Cloudy swelling and congestion were significantly more prevalent in the kidneys of group III than group IV; photomicrograph (2a) and (2b) Also, there were significant higher prevalence of atheroma in the heart of group III than group IV $(70 \%$ vs zero, $\mathrm{p}=0.003)$; photomicrograph (3a), (3b) and (3c). As regards histopathological changes in the 
lung, group III showed a significant higher prevalence of moderate and severe interstitial inflammation and granuloma around cholesterol crystal than group IV
(30\% and $60 \%$ vs $10 \%$ and $10 \%$; respectively), $\mathrm{p}=0.006$; photomicrograph (4a) and

(4b).

Table (6): Comparison between group III and group IV regarding histopathological changes of the studied organs.

\begin{tabular}{|c|c|c|c|c|}
\hline Histopathological changes & $\begin{array}{l}\text { Group III } \\
(\mathbf{n}=10) \\
\text { No }(\%)\end{array}$ & $\begin{array}{l}\text { Group IV } \\
(\mathbf{n}=10) \\
\text { No }(\%)\end{array}$ & $\chi^{2}$ & p-value \\
\hline \multicolumn{5}{|l|}{ Liver } \\
\hline $\begin{array}{l}\text { Steatosis: } \\
\text { Negative } \\
\text { Mild } \\
\text { moderate }\end{array}$ & $\begin{array}{l}0 \\
2(20.0) \\
8(80.0)\end{array}$ & $\begin{array}{l}5(50.0) \\
4(40.0) \\
1(10.0)\end{array}$ & 11.11 & 0.004 \\
\hline $\begin{array}{l}\text { Congestion: } \\
\text { Negative } \\
\text { Mild } \\
\text { moderate } \\
\end{array}$ & $\begin{array}{l}0 \\
7(70.0) \\
3(30.0)\end{array}$ & $\begin{array}{l}6(60.0) \\
3(30.0) \\
1(10.0) \\
\end{array}$ & 8.60 & 0.014 \\
\hline $\begin{array}{l}\text { Hepatitis: } \\
\text { Negative } \\
\text { Mild } \\
\text { moderate } \\
\text { severe } \\
\end{array}$ & $\begin{array}{l}0 \\
1(10.0) \\
3(30.0) \\
6(60.0) \\
\end{array}$ & $\begin{array}{l}6(60.0) \\
2(30.0) \\
1(10.0) \\
1(10.0)\end{array}$ & 10.90 & 0.012 \\
\hline \multicolumn{5}{|l|}{ Heart } \\
\hline $\begin{array}{l}\text { No changes } \\
\text { Mild congestion } \\
\text { Cholesterol crystal } \\
\text { atheroma }\end{array}$ & $\begin{array}{l}0 \\
3(30.0) \\
0 \\
7(70.0)\end{array}$ & $\begin{array}{l}5(50.0) \\
3(30.0) \\
2(20.0) \\
0\end{array}$ & 14.00 & 0.003 \\
\hline \multicolumn{5}{|l|}{ Lung } \\
\hline $\begin{array}{l}\text { No changes } \\
\text { Mild interstitial infiltration } \\
\text { Moderate interstitial } \\
\text { infiltration+ granuloma around } \\
\text { cholesterol crystals } \\
\text { Severe interstitial infiltration+ } \\
\text { granuloma around cholesterol } \\
\text { crystals }\end{array}$ & $\begin{array}{l}0 \\
1(10.0) \\
3(30.0) \\
6(60.0)\end{array}$ & $\begin{array}{l}5(50.0) \\
3(30.0) \\
1(10.0) \\
1(10.0)\end{array}$ & 10.57 & 0.014 \\
\hline \multicolumn{5}{|l|}{ Kidney } \\
\hline $\begin{array}{l}\text { No changes } \\
\text { Mild congestion } \\
\text { Moderate congestion } \\
\text { Marked congestion } \\
\text { Cloudy swelling }\end{array}$ & $\begin{array}{l}0 \\
0 \\
2(20.0) \\
3(30.0) \\
5(50.0)\end{array}$ & $\begin{array}{l}6(60.0) \\
2(20.0) \\
1(10.0) \\
1(10.0) \\
0\end{array}$ & 14.33 & 0.006 \\
\hline
\end{tabular}

\begin{tabular}{|l|l|l|}
\hline P1: group I vs group II & P3: group I vs group IV & P5: group II vs group IV \\
\hline
\end{tabular} P2: group I vs group III P4: group II vs group 1 P6: group III vs group III IV 


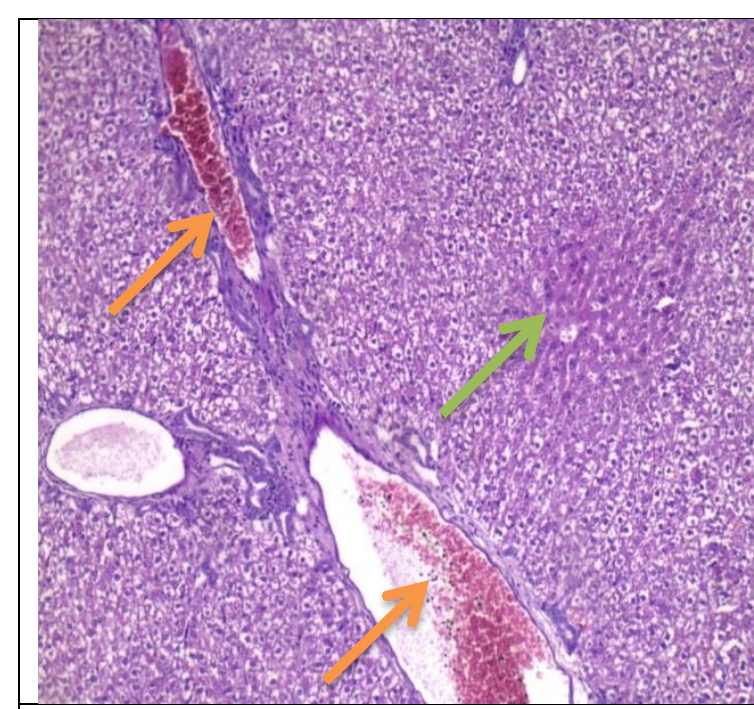

Photomicrograph (1a) Group III: Section of liver tissue showing marked congestion of central veins and portal tracts [yellow arrow]. The surrounding hepatic lobules showed moderate steatosis [green arrow] (H\&Ex100)

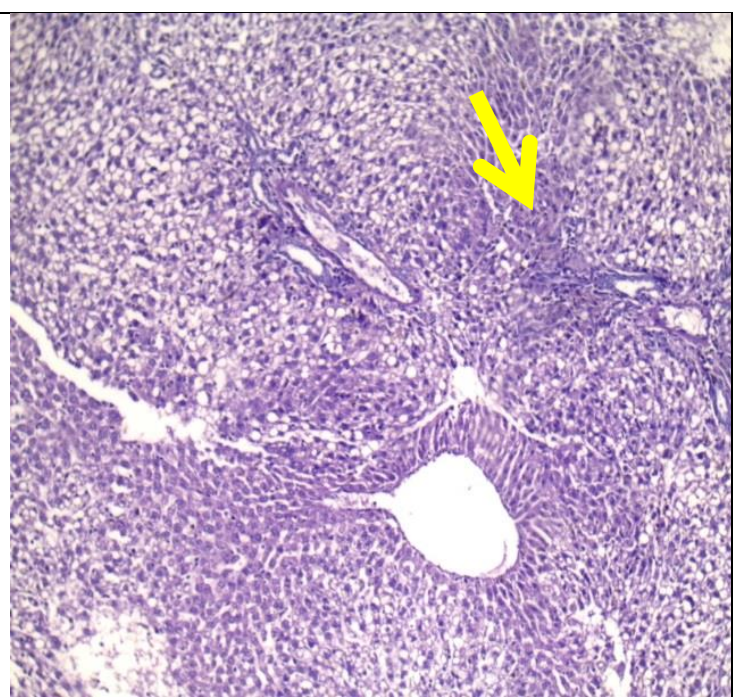

Photomicrograph (1b): group III: Section of liver tissue showing moderate steatosis of hepatocytes and mild infiltration of portal tract by inflammatory cells [arrow] (H\&Ex100)

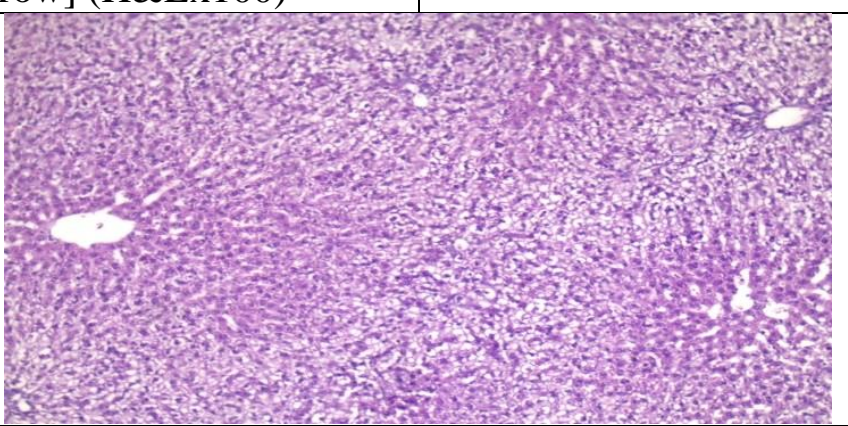

Photomicrograph (1c) Group IV: Section of liver tissue showing hepatic lobules with centrally oriented central veins surrounded by cords of hepatocytes. Some of hepatocytes showed cytoplasmic fat vacuoles (H\&Ex40)

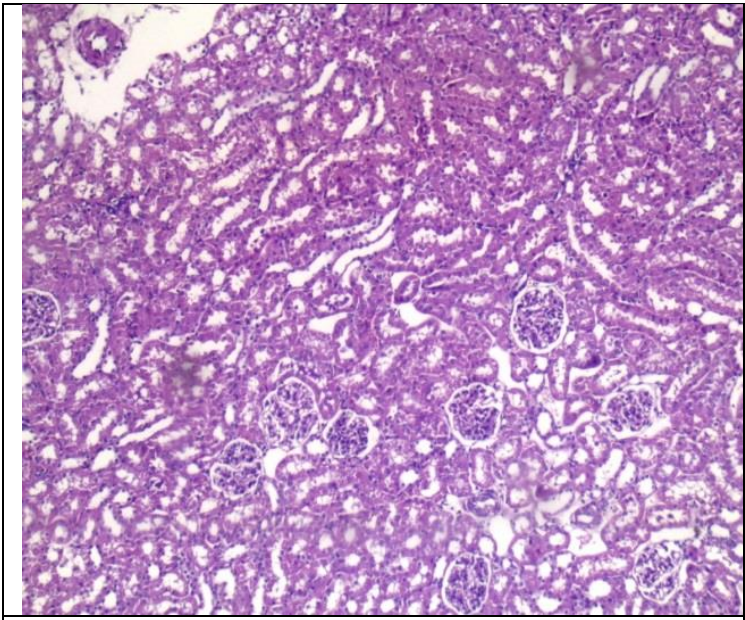

Photomicrograph (2a) group III: Section of kidney tissue showing mild cloudy swelling of renal tubules $(H \& E x 40)$

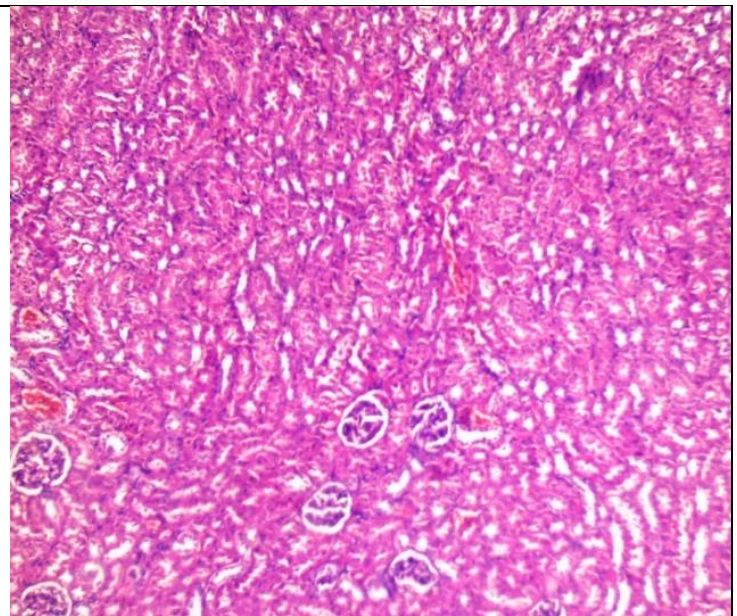

Photomicrograph (2b) group IV: section of kidney tissue showing no change of renal tubules $(\mathrm{H} \& \mathrm{Ex} 40)$ 


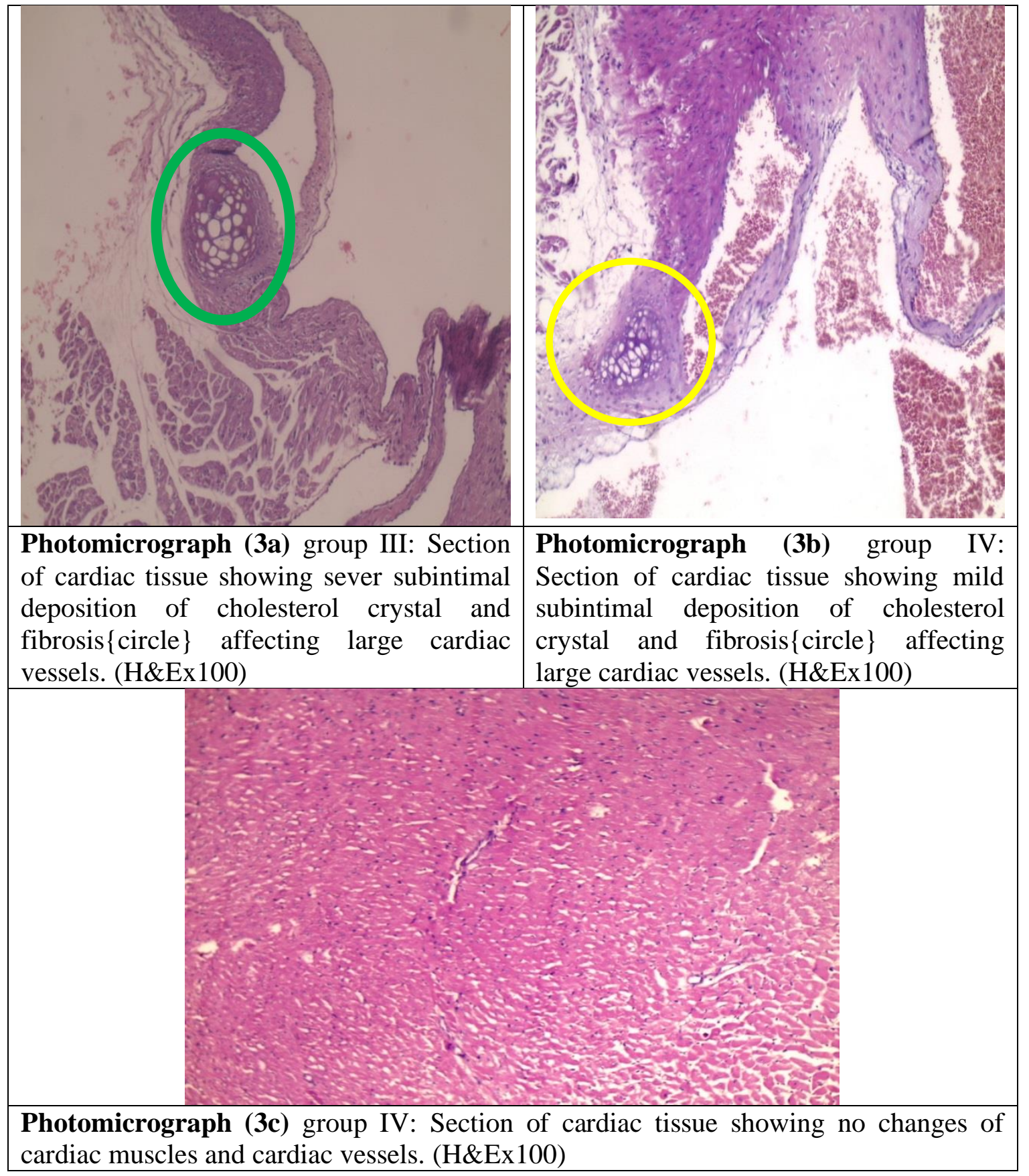




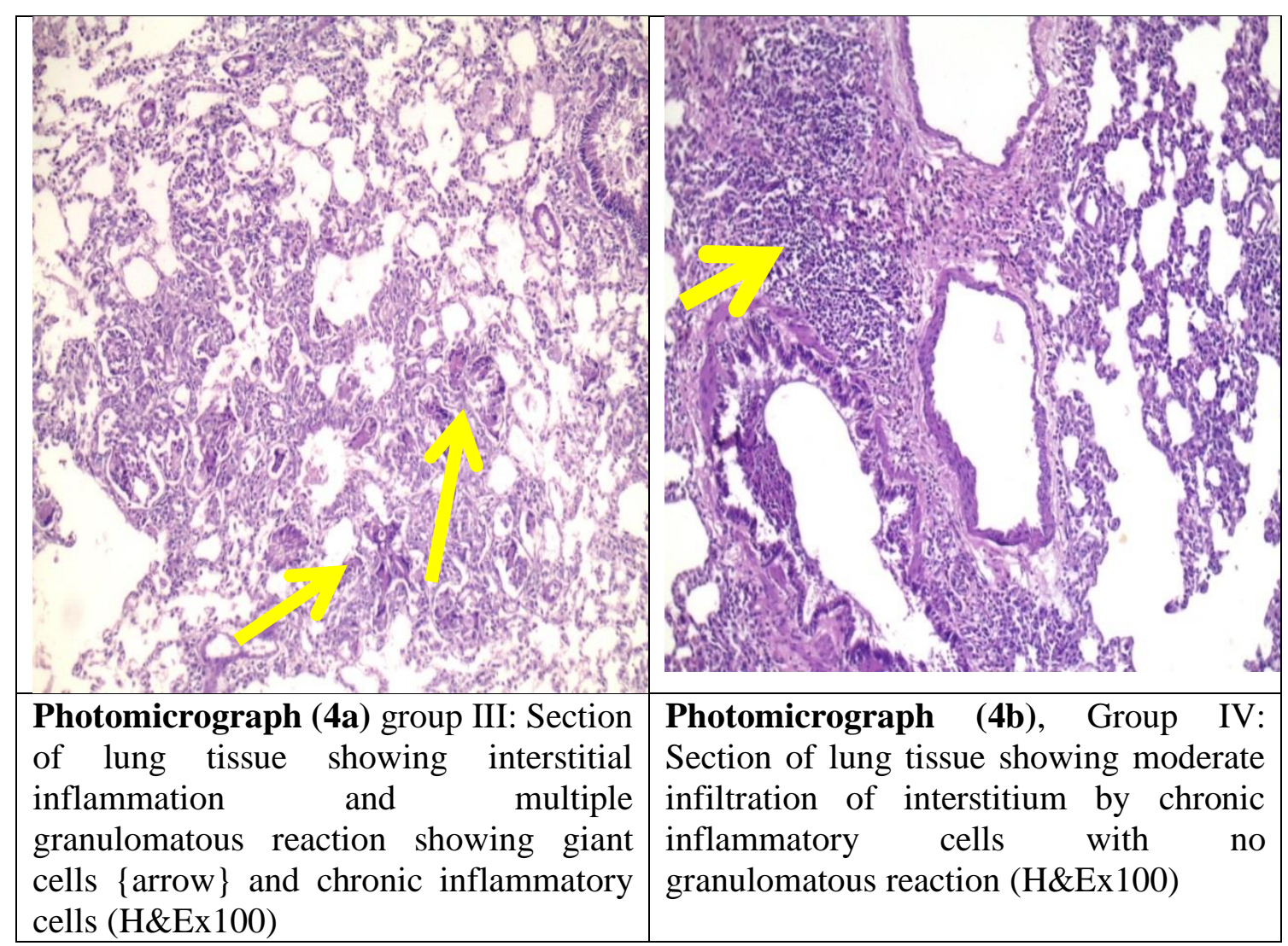

\section{DISCUSSION}

The present study aimed to investigate the biochemical and pathological toxic effects of thermally oxidized palm oil on albino rats and the potential protective role of Indian Costus against these effects. The study revealed significant elevations of lipid profile indices with lowered levels of HDL in group III that was fed with thermally oxidized palm oil than the control group I. These parameters were significantly improved when Indian Costus was (given with thermally oxidized palm oil) given to the animals in group IV. In addition, the levels of cholesterol, TG, LDL and total lipid were significantly lowered in group II that was given with Indian Costus than group I. These findings might suggest the protective effects of Indian Costus against hyperlipidemia.

Previous studies had also documented that intake of heated palm oil increased low-density lipoprotein (LDL) and cholesterol levels (Jaarin et al., 2006; Falade et al., 2015). The decline in TAC, LDL, HDL and TG levels in Albino rats treated with Indian Costus in this study agreed with the findings of Bavarva and Narasimhacharya (2008). Also, the use of $20 \mathrm{mg} / \mathrm{kg}$ body weight of costunolide (hypolipidemic drug isolated from Costus speciosus) in diabetic rats, significantly decreased the plasma levels of total cholesterol, TG, and LDL (Eliza et al., 2009). The hypocholesterolemic effect of Costus speciosus rhizomes might be due to the presence of phytochemicals especially flavonoids and other phenolic compounds (Jha et al., 2010), which have been reported as scavengers of free radicals.

The significant elevation in Malondialdehyde (MDA) levels a marker for lipid peroxidation and lowered TAC (total antioxidant capacity)levels in thermally oxidized palm oil treated groups compared to the control group in our study may suggest that thermal oxidation of palm oil might increase free radical formation which is in agreement with a study of Adam et al. (2008). Moreover, increasing heating times was associated with a significant increase in the MDA content of the oil (in animal not in oil) due to the breakdown of peroxides to carbonyl and 
aldehyde compounds such as malondialdehyde (Serjouie et al., 2010). Although lipid peroxidation may be prevented initially by antioxidants such as vitamin $\mathrm{E}$ in palm oil, but the repeated heating also destroys vitamin $\mathrm{E}$ content (Adam et al., 2007). Malondialdehyde (MDA) causes endothelial damage, vascular inflammation and cell membrane injury (Adam et al., 2009). MDA levels were significantly decreased when Indian Costus was (given with) added to thermally oxidized palm oil. A study conducted by Kotebagilu et al. (2014) reported that medicinal plants such as Costus speciosus have antioxidant potency and the ability to inhibit oxidation in red blood cells and microsomes due to its content of flavonoid and polyphenol.

Liver enzymes (ALT and AST) were significantly elevated in group III that was gavaged with thermally oxidized palm oil and these findings were associated with pathological changes in the liver such as steatosis, congestion and hepatitis. These results might be due to excessive storage of lipids in the liver that leads to liver damage. Our findings agreed with Falade et al. (2015) who revealed that there was a significant increase in the activities of ALT, AST of the thermally oxidized palm oil group when compared with the control. Moreover, Chatuphonprasert et al. (2019) found that, the hepatic tissues of mice that consumed reused palm oil for 36 weeks showed much more damage and the hepatocytes had become swollen with extensive fat droplet accumulation, hepatocyte degeneration, damage to sinusoid structure, and loss of hepatic architectural integrity.

Indian Costus improve both biochemical and the histopathological changes in the present study when indicated with thermally oxidized palm oil in group IV. Treatment of the hypercholesterolemic mice with aqueous extract of Indian Costus caused reduction in the activity of liver enzymes was reported by previous studies (Eliza et al., 2009; Saad et al., 2018).

Cloudy swelling of renal tubules with moderate to marked congestion was observed in the kidney with thermally oxidized palm oil in this study. This indicates that renal hypoxia could arise secondary to lipid peroxidation with subsequent atherosclerosis. These pathological changes weren't associated with significant changes in serum creatinine or B2 microglobulin levels; these effects might be changed with prolonged use. Similarly, Jaarin et al. (2016) found that the use of heated palm oil in rats causes tubular congestion and inflammation and these histological changes were not accompanied by an increase in serum creatinine level. Palm oil, being a mono-saturated oil may have less detrimental effects on the kidney compared to unsaturated fat or oil. In contrast, Ani et al. (2015) reported that the use of heated palm oil for 6 months increases serum creatinine levels in rabbit compared to the respective baseline readings and had detrimental nephrotoxic effects. The difference of these results from our results could be explained using rabbits and the more time of the study.

Uboh et al. (2014), reported that Costus afer leaves' juice on nitrocellular thinner nephrotoxicity in rats due to inhibition of lipid peroxidation and radical scavenging due to its phytoconstituents such as flavonoids, alkaloids, saponins, phenols, terpenoids, tannins, and cardiac glycosides and this might explain the ameliorated effect of Indian Costus on renal pathology in the present study.

The pathological changes of thermally oxidized palm oil in this study on the heart included congestion, cholesterol crystal and atheroma. Also, the cardiotoxic effect of thermally oxidized palm oil including vascular inflammation and dysfunction was revealed by $\mathbf{~ N g}$ et al. (2012). These changes could be due to hyperlipidemia in addition to the oxidative stress. Therefore, the addition of Indian Cosuts in group IV 
improved the pathological changes induced by the oxidized palm oil. The vascular protective effects of antioxidants were demonstrated in several studies (de Souza et al. 2010), vascular inflammation (Mukai and Sato 2011) and improvement in endothelial function (Widmer et al. 2013).

These were no significant elevation in CK-MB or LHD enzymes that released from the damaged myocardium (Penttilä et al. 2000) in the present study. This might be explained by the instability of theses enzymes in plasma after their release from damaged tissues (Al-Hadi et al. 2009).

Interstitial pneumonitis with granuloma around cholesterol crystals were detected in lung pathology associated with thermally oxidized oil. Intra-alveolar cholesterol granulomas result from the accumulation of endogenous cholesterol esters in the alveolar and interstitial spaces with lymphocytic infiltrations and alveolar wall-thickening (Zhang et al. 2016).

\section{CONCLUSION}

These findings suggest that thermally oxidized palm oil had a deleterious effect on liver, kidney, lung and heart ultrastructure, induces hyperlipidemia and oxidative stress. The aqueous extract of Indian costus had a potential protective effect against these effects.

\section{RECOMMENDATION}

- Cooking with and/or consumption of repeatedly heated palm oil should be discouraged in our homes as this might have deleterious effects on human health.

- The aqueous extract of Indian Costus could be used as hypolipedemic and antioxidant therapeutics.

- More wide scales researches on the protective role of Indian Costus on the harmful effects of thermally oxidized palm oil for longer duration and using different doses were recommended.

\section{REFERENCES}

Abd Eldaim, M.A.; Tousson, E. ; El Sayed, I.E and Awd, W.M. (2019): Ameliorative effects of Saussurea lappa root aqueous extract against Ethephon-induced reproductive toxicity in male rats. Environmental Toxicology, 34:150-159.

Adam, S.K.; Das, S. and Jaarin K. (2009): A detailed microscopic study of the changes in the aorta of experimental model of postmenopausal rats fed with repeatedly heated palm oil. Int. J. Exp. Pathol., 90: 321-327.

Adam, S.K.; Sulaiman, N.A.; Mohamed, N. and Jaarin, K. (2008): Effects of repeatedly heated palm oil on serum lipid profile, lipid peroxidation and homocysteine levels in a postmenopausal rat model. McGill Journal of Medicine, 11 (2): 145-151.

Adam, S.K.; Sulaiman, N.A. ; Mat Top, A.G. and Jaarin, K. (2007): Heating reduces vitamin $\mathrm{E}$ content in palm and soy oils. Malays J Biochem Mol Biol., 15 (2):76-79.

AL-Kattan, M.O. (2013): Anti-bacterial effect of Indian costus and sea-qust and their water extracts on some pathogenic bacteria of the human respiratory system. Journal of Medicinal Plants Research, 7 (20):1418-1423

Amara, U.; Mashwani, Z.R.; Khan, A.; Laraib, S.; Wali, R.; Sarwar, U.; et al (2017): Conservation Status and Therapeutic Potential of Saussurea lappa: An Overview. American Journal of Plant Sciences, 8: 602-614

Ani, E.J.; Victor, U.; Daniel, N.U. and Osim, E.E. (2015): Effect of Chronic consumption of two forms on palm oil diet on serum electrolyte, creatinine and urea in rabbits. J. Appl. Pharmaceutical Sci., 5: 115-119.

Bassan, A.; Fioravanzo, E.; Pavan, M. and Conto, A. (2012): Reports on toxicokinetics, toxicity and allergenicity data on substances to be 
evaluated as acceptable previous cargoes for edible fats and oil. Supporting Publications: EN-274.

Bavarva, J.H. and Narasimhacharya, A.V. (2008): Antihyperglycemic and hypolipidemic effects of Costus speciosus in alloxan induced diabetic rats. Phytother Res, 22 (5): 620-626.

Brunt, E.M. (2000): Grading and staging the histopathlogical lesions of chronic hepatitis: The Knodell Histology activity Index and Beyond. Hepatology, 31 (1): 241-246.

Chandrasekharan, N.; Sundram, K. and Basiron, Y. (2000): Changing nutritional and health perspectives on palm oil. Brunei International Medical Journal, 2: 417 - 427.

Chatuphonprasert, W. ; Sriset, Y.; Jarukamjorn, K. (2019): Continuous Consumption of Reused Palm Oil Induced Hepatic Injury, Depletion of Glutathione Stores, and Modulation of Cytochrome P450 Profiles in Mice. Pol. J. Food Nutr. Sci., 69 (1): 53-61.

de Souza, M.O.; Silva, M.; Silva, M.E.; Oliveira, R. de P. and Pedrosa, M.L. (2010): Diet Supplementation with Acai (Euterpe Oleracea Mart.) Pulp Improves Biomarkers of Oxidative Stress and the Serum Lipid Profile in Rats. Nutrition, 26 (7): 804-810.

Doumas, B.; Watson, W. and Biggs, H. (1971): Albumin standard and the measurement of serum albumin with bromocresol green. Clin. Chim. Acta, 31: 87-96.

Eliza, J.; Daisy, P.; Ignacimuthu, S. and Duraipandiyan, V. (2009): Normoglycemic and hypolipidemic effect of costunolide isolated from Costusspeciosus (Koen.)Sm. in streptozotocin-induced diabetic rat, Journal of Chemico-Biological Interactions, 179: 329-334.

Falade, A.O.; Oboh, G.; Ademiluyi, A. and Odubanjo, O. (2015): Consumption of thermally oxidized palm oil diets alters biochemical indices in rats, Beni-Suef University
Journal of Basic and Applied Sciences, 151-154.

Gwari, G.; Bhandari, U.; Andola, H.; Lohani, H. and Chauhan, N. (2013): Volatile constituents of Saussurea costus cultivated from Uttarakh and Himalayas, India. Pharmacogn Res., 5: 179-182.

Henderson, A. and Moss, D. (2001): Enzymes, Tietz Fundamentals of Clinical Chemistry 5th Edition, In: Burtis, C.A., Ashwood, E.R. W.B. Saunders (eds), Philadelphia, USA.352.

Henry, R. J. (1974): Clinical chemistry. Principals and technics. Harper and Row; $2^{\text {nd }}$ edition. 525.

Ismail, R. (2005): Palm oil and palm olein frying applications. Asia Pac J Clin Nutr, 14 (4): 414-419.

Jaarin, K.; Norhayati, M.; Norzana, G.; Nor Aini, U. and Ima-Nirwana, S. (2006): Effects of vegetable oils on serum lipids and aorta of ovariectomized rats. Pakistan J Nutri., 5(1):19-29.

Jha, M.K.; Alam, M.B.; Hossain, M.S. and Islam A. (2010): In vitro antioxidant and cytotoxic potential of Costus speciosus (Koen.) Smith rhizome. Int $\mathrm{J}$ Pharm Sci Res, 1 (10):138-144.

Kaplan, A. (1984): Urea. Clin. Chem. The C.V.Mosby Co. St Louis. Toronto. Princeton.1257-1260.

Kleiner, D.E.; Brunt, E.M.; Van Natta, M.; Behling, C.; Contos, M.J. and Cummings, O.W.; et al. (2005): Design and validation of a histological scoring system for nonalcoholic fatty liver disease; Hepatology, 41(6); 1313-1321.

Koracevic, D.; Koracevic, G.;Djordjevic, V. and Andrejevic (2001): Method for the measurement of antioxidant activity in human fluids. J Clin Pathol, May, 54 (5):356-361.

Kotebagilu, N., Palvai, V., and Urooj, A. (2014): Protective effect of selected medicinal plants against hydrogen 
peroxide induced oxidative damage on biological substrate. International Journal of Medicinal Chemistry, Article ID 861084, 7 pages http://dx.doi.org/10.1155/2014/861084

Mukai,Y. and Sato, S. (2009): Polyphenol-Containing Azuki Bean (Vigna Angularis) Seed Coats Attenuate Vascular Oxidative Stress and inflammation in sponaneously hypertensive rats. The Journal of nutritional Biochemistry, 22 (1): 1621.

Mukherjee, S and Mitra, A. (2009): Heath effects of palm oil. J Hum Ecol, 26 (3): 196-203.

Ng, C.Y; Kamisah, Y.; Faizah, O.; Jubri, Z.; Qodriyah, H.S. and Jaarin K. (2012): Involvement of Inflammation and Adverse Vascular Remodelling in the Blood Pressure Raising Effect of Repeatedly Heated Palm Oil in Rats. International Journal of Vascular Medicine, Volume 2012, Article ID 404025, 10 pages http://dx.doi.org/10.1155/2012/404025

Nwalieji, H.U. and Ojike, H.U. (2018): Characteristics of Small-Scale Palm Oil Production Enterprise in Anambra State. Journal of Agricultural Extension, 22(1): 22-34

Obembe, A.O.; Owu, D.U.; Okwari, O.O.; Antai, A.B. and Osim, E.E. (2011): Intestinal Fluid and Glucose Transport in Wistar Rats following Chronic Consumption of Fresh or Oxidised Palm Oil Diet. International Scholarly Research Network ISRN Gastroenterology Volume 2011, Article ID 972838, 5 pages doi:10.5402/2011/972838

Obeten, K.E.; Igiri1, A. O. and Mfem, C. C (2014): Studies on the Chronic Consumption of Thermo Oxidized Palm Oil on the Histomorphology of the Cerebellum in Mice. Journal of Biology, Agriculture and Healthcare, 4 (11): 102-105. Ohkawa, H.; Ohishi, N. and Yagi K. (1979): Assay for lipid peroxides in animal tissues by thiobarbituric acid reaction. Anal Biochem., 95(2): 351358.

Pandey, M.M.; Rastogi, S. and Rawat, A.K. (2007): Saussurea costus: botanical, chemical and pharmacological review of an ayurvedic medicinal plant. J Ethnopharmacol, 4; 110 (3): 379-390.

Parmar, M.P.S.; Negi, L.S. and Ramola $S$ (2012): Seeds Germination and Seedlings Analysis of Saussurea Costus Royle Ex Benth. In High and Low Altitudinal Villages of District Uttarkashi. Journal of Pharmacy, (2) 6: 25-30.

Penttilä, I.; Penttilä, K. and Rantanen T. (2000): Laboratory diagnosis of patients with acute chest pain. Clin Chem Lab Med, 38 (3): 187-197.

Pesce, A. (1984): Lactate Dehydrogenase. Kaplan, et al. Clin. Chem. The C.V. Mosby Co. St Louis. Toronto. Princeton, $1124-117,428$.

Ramos-Vara, J., Wohlwend, A., Scheluning, W. and Kruithof $K$. (2017): Principles and Methods of Immunohistochemistry. Methods Mol Biol, 1641:115-128.

Rifai, N.; Warnick, G.R. and Nauck, M. (2006): Evolution of methods for measurement of HDL-cholesterol: from ultracentrifugation to homogeneous assays. Clin Chem, 259 (3): 247-258.

Saad, K.; Alkailani, H.; Mohamad, N.; Saeed, S. and Mohamed, F. (2018): Aqueous extract of Indian costus roots effects on a diet-induced hypercholesterolemia in murine model. Int. J. Adv. Res., 6 (7): 25-29.

Saleem, T.S.; Lokanath, N.; Prasanthi, A. M.; Madhavi, M.; Mallika, G. and Vishnu, M.N. (2013): Aqueous extract of Saussurea lappa root ameliorate oxidative myocardial injury induced by isoproterenol in rats. $\mathrm{J} \mathrm{Adv}$ Pharm Technol Res, 4(2): 94-100.

Scherwin, J.E. (2003): Liver function. Clinical Chemistry: Theory, Analysis, 
Correlation. $4^{\text {th }}$ Ed., Kaplan LA, Pesce AJ and Kazmierczak SC., Mosby Inc. eds. St Louis USA. 492 and appendix.

Serjouie, A.; Tan, C.; Mirhosseini, H. and Man Y (2010): Effect of vegetable-based oil blends on physicochemical properties of oils during deep-fat frying. American Journal of Food Technology, 5 (5), 310-323.

Singh, R.; Chahal, K.K. and Singla N (2017): Chemical composition and pharmacological activities of Saussurea lappa: A review. Journal of Pharmacognosy and Phytochemistry, 6 (4): 1298-1308.

Tonkiri, A.; Essien, E.B.; Akaninwor, J.O. and Ogbomade RS (2015): Protective Effect of Costus afer on Lipid Profile and Hepatic Damage in Ethanol - Induced Liver Cirrhosis in Rats. Int J Biochem Res, Rev 6: 53-61.

Turbat-Herrera, E.A. (1994). B2 microglobulin and the kidney: An overview. Ultrastructural pathology, 18: $99-103$.

Uboh, F.E.; Saviour, U.; Eve, M. and Eyong, E.U. (2014): Effect of costusafer Leaves' juice on

nitrocellular thinner induced nephrotoxicity in rats. Res $\mathrm{J}$ of Environ Toxicol., 8 (1): 37- 45.

Widmer, R.J.; Freund, M.A.; Flammer, A.J.; Sexton, J.; Lennon, R.; Romani, A.; et al (2013): A Beneficial Effects of Polyphenol-Rich Olive Oil in Patients with Early Atherosclerosis. European Journal of Nutrition, 52 (3): 1223-1231.

Young, D.S. (2001): Effect of diseases on clinical lab. Tests. $4^{\text {th }}$ edition AACC press.

Zahara, K.; Tabassum, S.; Sabir, S.; Arshad, M.; Qureshi, R.; Shoaib Amjad, M.; et al. (2014): A review of therapeutic potential of Saussurea lappa-An endangered plant from Himalaya Asian Pac J Trop Med, 7(1): 60-69.

Zhang, M.; Tie, H.T.; Wang, C.L. and Wu, Q.C. (2016): Pulmonary interstitial cholesterol crystals associated with diffuse lung cysts in adult: a case report and literature review. J Cardiothorac Surg., 11: 11. 


\section{دور القسط الهندي ضد التأثير السام لزيت النخيل المؤكسد حراريا في الجرذان البيضاء}

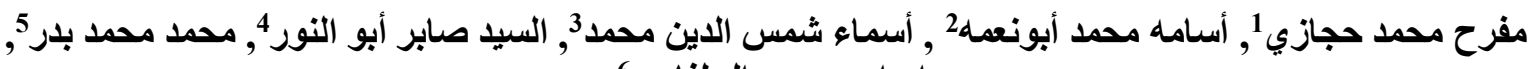
إبراهيم عبده الحلفاوي6.

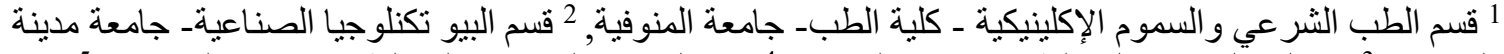

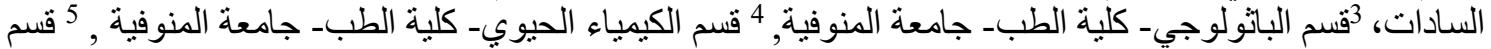

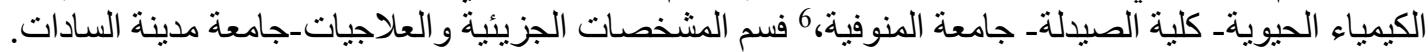

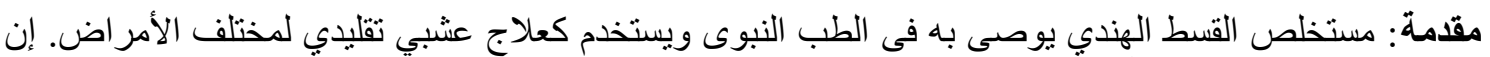

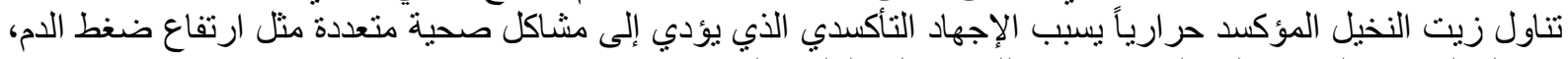

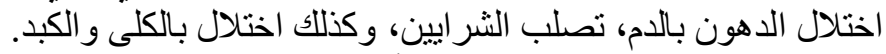

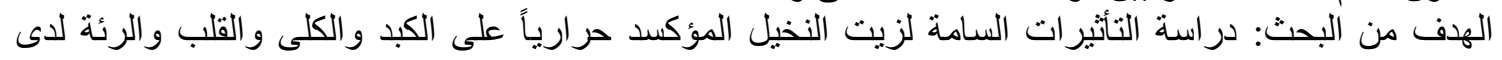

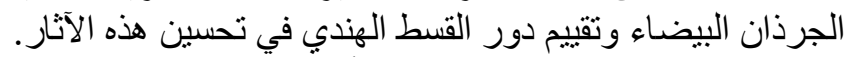

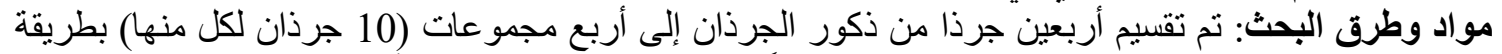

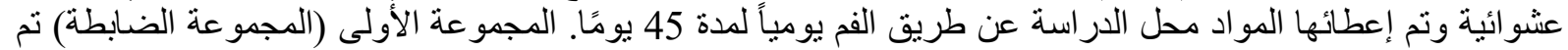

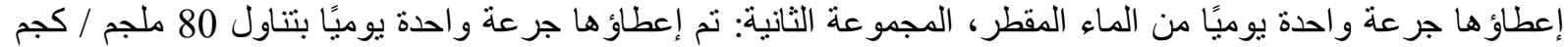

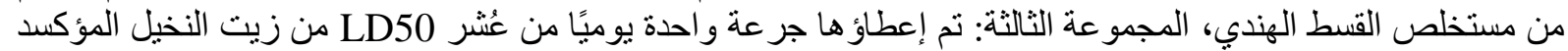

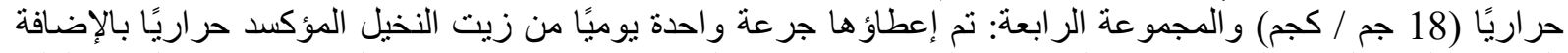

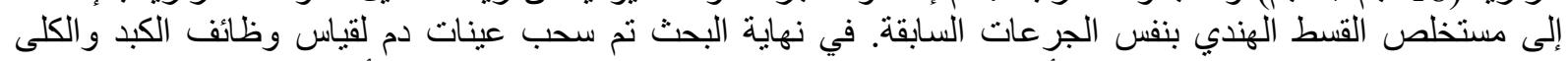

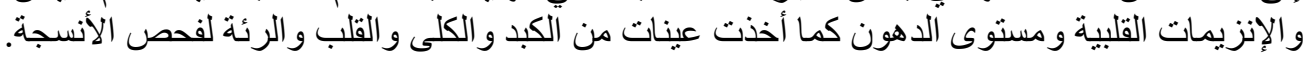

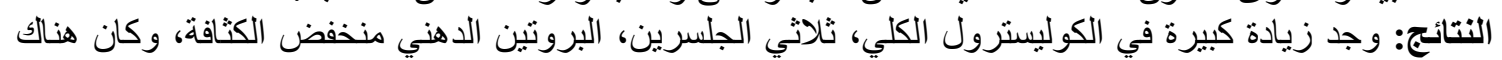

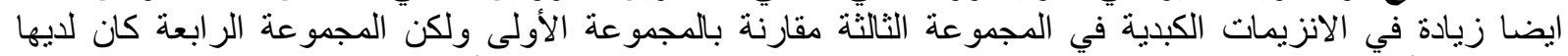

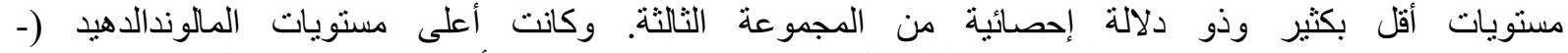
كان (MDA Malondialdehyde

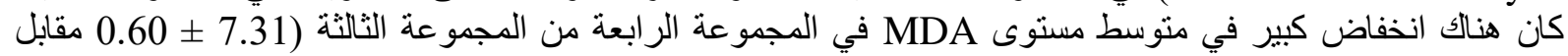

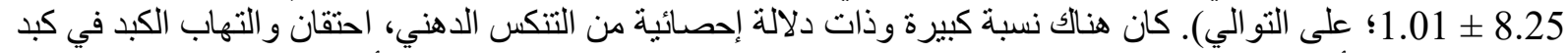

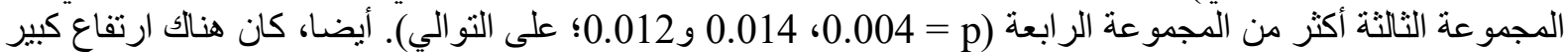

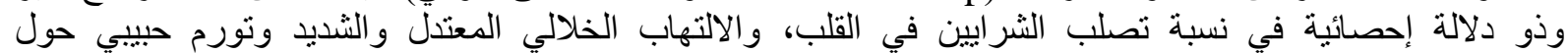

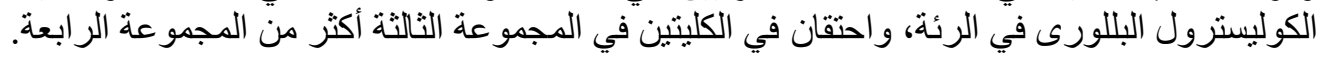

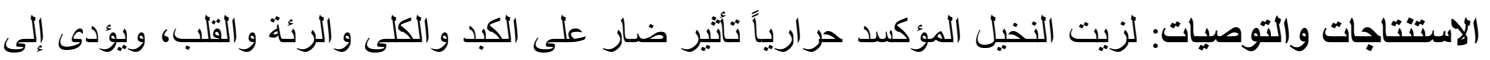

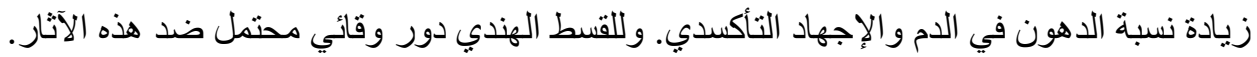

